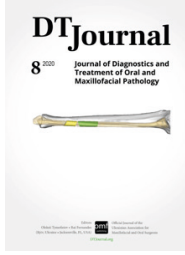

\title{
Covid-2019 Pandemic: Growing Wave of Cancelled Meetings in Oral and Maxillofacial Surgery and Its Impact on Specialty
}

\author{
Francesco Maffia ${ }^{a}$, levgen I. Fesenko ${ }^{b}$ \& Valentino Vellone
}

We are at war. All our energy should be on one aim: to slow the progress of the virus. ${ }^{1}$ -Emmanuel Macron French President (March 16, 2020)

The official cause of the coronavirus disease 2019 (Covid-19) ${ }^{2}$ became a novel severe acute respiratory syndrome coronavirus 2 (SARS-CoV-2) ${ }^{3}$ which was officially identified on January 9, 2020. ${ }^{4}$ Generally described four transmission routes for the Covid-19: 1) aerosol transmission, 2) contact transmission, 3) droplets transmission, and even through 4) digestive system. ${ }^{3}$ The most commonly reported symptoms in patients are cough, fever, myalgia/fatigue, pneumonia, and complicated dyspnea. ${ }^{3,5}$ According to Li et al cases resulting in death were primarily in elderly and middle-aged patients with pre-existing co-morbidities. ${ }^{6}$ The statistically proved number of death worldwide continues permanently to increase. On March 26 that number of death reached 21,297 people, ${ }^{7}$ on April 1 - 42,341 people, ${ }^{8}$ on April 7 - 74,820 people, ${ }^{9}$ on May 29 - 362,091 ${ }^{10}$, and on

\footnotetext{
${ }^{a} \mathrm{MD}$, Department of Odontostomatological and Maxillofacial Sciences, "La Sapienza" University of Rome, Rome, Italy.

E-mail: francesco.maffia@gmail.com

Instagram: @francesco.maffia

${ }^{\mathrm{b}}$ Managing Editor, dtjournal.org, Kyiv, Ukraine.

E-mail: i.i.fesenko@dtjournal.org

Instagram: @dr_eugenfesenko

${ }^{c}$ MD, PhD Student, Department of Odontostomatological and

Maxillofacial Sciences, "La Sapienza" University of Rome, Rome, Italy.

E-mail: valentino.vellone@gmail.com
}

Instagram: @dr.vellone.maxillo
August $11-739,342^{11}$. Among many governments measures became: closed borders, quarantine, and "stay at home" order (excluding medicine and urgent dentistry workers). A 1,000-bed United States Navy hospital ship docked in New York, ${ }^{12}$ huge government's emergency field hospitals open in the exhibition convention centers ${ }^{13,14}$ around the globe. And the list of measures in different countries continues to an extent with one goal - to save more lives. Elective surgeries, except emergency and cancer cases surgeries, were also forbidden.

From the moment of closed borders, the wave of canceled scientific meetings starts to grow continually affecting the meetings industry, specialties, and continuing medical education. Among them, two very important spring oral and maxillofacial surgery (OMS) events were canceled: A 77th Annual Meeting of the American Cleft Palate-Craniofacial Association (ACPA) in Portland (scheduled from March 31 to April 4, 2020) $)^{15}$ and the 1st International Symposium on Orthognathic Surgery of the International Association of Oral and Maxillofacial

Please cite article as: Maffia F, Fesenko II, Vellone V. Covid-2019 pandemic: growing wave of cancelled meetings in oral and maxillofacial surgery and its impact on specialty. J Diagn Treat Oral Maxillofac Pathol 2020;4(8):125-8.

Paper received 2 June 2020

Revised 8 August 2020

Accepted 12 August 2020

Online 31 August 2020

https://dx doi.org/10.23999/j.dtomp.2020.8.1.

(C) 2020 OMF Publishing, LLC. This is an open access article under the CC BY license (http://creativecommons.org/licenses/by-nc/4.0/) 
Surgeons (IAOMS) in Vienna (scheduled from April 30 to May 2, 2020) $)^{16}$.

Dr. Maffia: The outbreak of SARS-CoV-2 has changed the world as we knew it. But changing is always so bad? Well, it's not, sometimes is needed. If we truly think about what we experienced it seems easy to find how many things changed in positive. Probably it was so much time this change was necessary. This situation brought us to make the changes that were needed by always. The revolution that the pandemic brought with itself forced the entire world to evolve, to find solutions to wellknown problems. I see this global change as the first square of a Domino's game.

With all the elective cases postponed, the biggest amount of work came from emergency surgeries as traumas, cancer, and infections, but also all the needed follow-ups. It's known how difficult can be to reach a hospital for a visit, especially if it's not in your city. Let's try to imagine the benefits of a telemedicine service to partially substitute the physical visit. It sounds amazing and very helpful. Of course, it can be considered as the first stratification between patients that can be visited virtually and patients that must reach the hospital. Anyhow, the net result is positive: less physical patients means less access to hospital and less risk of infection for both patients and personal, with a great simplification of the possibility to obtain a visit.

The Medical Education in this period had a great boost: students and residents could receive telematic meetings, recorded video lectures, and multidisciplinary symposiums. The effects of this new habit gave the occasion to obtain a provisory education not being anymore bonded to a particular time during the day. Free and useful contents were uploaded in many official sites of important associations of this specialty, like IAOMS $^{17}$ and $\mathrm{AOCMF}^{18}$. This movement represents a first step in the on-demand way to share knowledge, with the possibility to enjoy it whenever is more comfortable for the user.

The organization of congresses had his crisis: the impossibility to travel and to meet by person created another interesting phenomenon. Virtual Congresses represented the solution to this kind of problem, generating a wave of these initiatives in many fields, not only Oral and Maxillofacial Surgery but also Plastic Surgery ${ }^{19}$ and Dentistry ${ }^{20}$. Participation in these events has been very high and the choice of a common comfortable time zone created the possibility to accept users from all over the world.

About all what this situation created, a common denominator is evident: the possibility to work, collaborate, and share experiences or knowledge on a global scale. We have been separated for a while, but observing the set-up from a different angle, we have never been so united on a scientific and medical point of view. A clear example of this trend is represented by the initiative of the National Institute for Health Research (NIHR) Global Health Research Unit on Global Surgery ${ }^{21}$, a particular study in which all the specialties from all over the world will synchronize their work to collect data on patients undergoing surgery.

Literature has flourished in this period. Every specialty studied and shared the impact on its work, and, tile after tile, a mosaic was formed, painting the whole situation in the medical world. In conclusion, we experienced a pandemic spread of a novel coronavirus that brought also a huge boost of scientific medical knowledge. International collaborations were the pillars of this development, introducing the whole community to a new era. The physical distance might have been increased, but the scientific one has been reduced to a click.

Dr. Fesenko: The ACPA successfully organized seventy-six annual meetings from 1943 given its participants a wide range of tools for communication and collaboration on different projects, publications, etc. ${ }^{22}$ Cancellation of the 77th ACPA Annual Meeting (USA) in March 2020, like the whole pandemic, became a real surprise for the participants. Despite the cancellation, the ACPA's 77th Annual Meeting Abstracts were published on 143 pages of the open access special edition ${ }^{23,24}$ of The Cleft Palate-Craniofacial Journal (2018 impact factor: 1.471). ${ }^{25}$ Pandemic didn't stop the publication of 369 abstracts $^{24}$ in 10 categories which gave the scientists possibility to present their results to the global audience via internet and with gold open access. So, we can only applaud to the Meeting's organizers and SAGE Publishing who showed an example of how to be resilient in these difficult pandemic times.

Both meetings' organizers in this difficult pandemic situation gave the participants the refund options $^{8}$ what is also a great example of events management and adaptation for the new challenges.

But the main question is next. Is it possible to 
use cutting-edge internet technology and organize the virtual scientific event (meeting, congress, conference, or symposium) which will replace the meeting with physical attendance? Even the Interim Guidance of the Centers for Disease Control and Prevention stated that "when feasible, organizers could modify events to be virtual." 26,27 Javier Soltero, general manager and vice-president of $G$ Suite (Google Cloud, Google Inc.) ${ }^{28}$ announced at March 3 that their company "begin rolling out free access to their advanced Hangouts Meet video-conferencing capabilities to all G Suite and G Suite for Education customers globally including:

1. Larger meetings, for up to 250 participants per call.

2. Live streaming for up to 100,000 viewers within a domain.

3. The ability to record meetings and save them to Google Drive."

Recent publications emphasized that in Italy and Taiwan, university hospital staff are using Google Meet to continue lecturing to oral and maxillofacial surgery residents ${ }^{29}$ and in Ukraine - to educate students of "surgical dentistry" and "pediatric surgical dentistry" classes. ${ }^{30}$

Taking into account the possible huge number of participants (for example, the 15th Annual Dental Implant Conference gathered 1,500 participants ${ }^{31}$ it can be a challenge and a new task for the organizers how virtually manage such a number of attendees virtually.

At the initial stage of the pandemic, the meetings' organizers and visitors could think about how to replace the canceled OMS events with virtual ones. But very soon a huge vital measure to perform Covid-19 response conferences ${ }^{32}$ has emerged. One of them is a true role model event - OMFS COVID-19 Response Conference: Protecting Our Patients, Staff, and Ourselves. ${ }^{32}$ It's organized by the University of Pennsylvania and the program offers a free virtual attending 21 vital COVID-19-related speeches. Among the topics of the Conferences there are next ones: "Strategies for Protecting the Surgeon," "The Importance of OMFS to a Health System During COVID-19," "China Experience," and other extremely important lectures. ${ }^{26}$

In conclusion, we experienced a pandemic spread of a novel coronavirus that brought also a huge boost of scientific medical knowledge. International collaborations were the pillars of this development, introducing the whole community to a new era. We were given what is most precious, time. The time to increase our knowledge, to disseminate our findings via articles, and to improve ourselves as surgeons for our patients.

\section{REFERENCES}

1. 'We are at war' against the virus, says Macron [document on the internet]; March 16, 2020 [cited 2020 Apr 07]. Available from: https://www.ft.com/ content/d6c96612-67c0-11ea-800d-da70cff6e4d3.

2. WHO. Novel Coronavirus - China [document on the internet]; January 12, 2020 [cited 2020 Mar 25]. Available from: https://www.who.int/csr/don/12-january-2020novel-coronavirus-china/en/.

3. Adhikari S, Meng S, Wu Y. et al. Epidemiology, causes, clinical manifestation and diagnosis, prevention and control of coronavirus disease (COVID-19) during the early outbreak period: a scoping review. Infect Dis Poverty 2020;9(1):29.

4. Huang C, Wang Y, Li X, Ren L, Zhao J, Hu Y, Zhang L, Fan G, Xu J, Gu X, Cheng Z, Yu T, Xia J, Wei Y, Wu W, Xie X, Yin W, Li H, Liu M, Xiao Y, Gao H, Guo L, Xie J, Wang G, Jiang R, Gao Z, Jin Q, Wang J, Cao B. Clinical features of patients infected with 2019 novel coronavirus in Wuhan, China. Lancet 2020;395(10223):497-506.

5. Wu JT, Leung K, Bushman M. Kishore N, Niehus R, de Salazar PM, Cowling BJ, Lipsitch M, Leung GM. Estimating clinical severity of COVID-19 from the transmission dynamics in Wuhan, China. Nat Med 2020.

6. Li T, Wei C, Li W, Hongwei F, Shi J. Beijing Union Medical College Hospital on "pneumonia of novel coronavirus infection" diagnosis and treatment proposal (V2.0). Med J Peking Union Med Coll Hosp 2020.

7. Number of novel coronavirus (COVID-19) deaths worldwide as of March 25, 2020, by country [document on the internet]; March 26, 2020 [cited 2020 Mar 26]. Available from: https://www. statista.com/statistics/1093256/novel-coronavirus2019ncov-deaths-worldwide-by-country/

8. Number of novel coronavirus (COVID-19) deaths worldwide as of April 1, 2020, by country [document on the internet]; April 1, 2020 [cited 2020 Apr 1]. Available from: https:/www.statista.com/statistics/1093256/novelcoronavirus-2019ncov-deaths-worldwide-by-country/.

9. Number of novel coronavirus (COVID-19) deaths worldwide as of April 7, 2020, by country [document on the internet]; April 7, 2020 [cited $2020 \mathrm{Apr}$ 7]. Available from: https://www.statista.com/ 
statistics/1093256/novel-coronavirus-2019ncovdeaths-worldwide-by-country/.

10. Number of novel coronavirus (COVID-19) deaths worldwide as of May 29, 2020, by country [document on the internet]; May 29, 2020 [cited 2020 Jun 1]. Available from: https://www.statista.com/ statistics/1093256/novel-coronavirus-2019ncovdeaths-worldwide-by-country/.

11. Number of novel coronavirus (COVID-19) deaths worldwide as of August 11, 2020, by country [document on the internet]; August 11, 2020 [cited 2020 Aug 11]. Available from: https://www. statista.com/statistics/1093256/novel-coronavirus2019ncov-deaths-worldwide-by-country/.

12. Chang B. A 1,000-bed US Navy hospital ship just docked in New York to help the city brace for coronavirus - see inside the USNS Comfort [document on the internet]; March 30, 2020 [cited 2020 Apr 7]. Available from: https://www. businessinsider.com/new-york-1000-hospital-bednavy-hospital-ship-coronavirus-2020-3.

13. Coronavirus: Nightingale Hospital opens at London's ExCel centre [document on the internet]; April 3, 2020 [cited 2020 Apr 7]. Available from: https://www. bbc.com/news/uk-52150598.

14. Coronavirus: Madrid conference centre becomes temporary hospital [document on the internet]; March 22,2020 [cited 2020 Apr 7]. Availablefrom:https://en.as. com/en/2020/03/22/album/1584882887_210391.html.

15. ACPA's Annual Meeting [document on the internet]; March 25, 2020 [cited 2020 Mar 25]. Available from: https://acpa-cpf.org/annual-meeting/.

16. Vienna Symposium 2020 [document on the internet]; March 25, 2020 [cited 2020 Mar 25]. Available from: https://www.iaoms.org/education/vienna2020/.

17. IAOMS Microlearning Series [document on the internet]; August 8, 2020 [cited 2020 Aug 8]. Available from: https://www.iaoms.org/education/ iaoms-microlearning-series/.

18. AOCMF: AOCMF Online Campus [document on the internet]; August 8, 2020 [cited 2020 Aug 8]. Available from: https://aocmf3.aofoundation.org/ education/online-campus.

19. EDMED: conservative rhinoplasty: online webinar [document on the internet]; August 8, 2020 [cited 2020 Aug 8]. Available from: https://cakir.edmed.ru/en/.

20. EDSA: Virtual World Congress of Dental Students 2020 [document on the internet]; August 8, 2020 [cited 2020 Aug 8]. Available from: https://www. edsaweb.org/virtual-congress-of-dental-students.

21. (NIHR) Global Health Research Unit on Global
Surgery: GlobalSurg | CovidSurg Week [document on the internet]; August 8, 2020 [cited 2020 Aug 8]. Available from: https://globalsurg.org/surgweek/.

22. ACPA's 75th Anniversary [document on the internet]; March 26, 2020 [cited 2020 Mar 26]. Available from: https://acpa-cpf.org/about-acpa/acpas-75thanniversary/.

23. Annual Meeting Update from ACPA [document on the internet]; March 26, 2020 [cited 2020 Mar 26]. Available from: https://acpa-cpf.org/2020/03/23/ annual-meeting-update-from-acpa/.

24. ACPA's 77th Annual Meeting Abstracts. Cleft PalateCran J 2020;57(Suppl.):1-143.

25. The Cleft Palate-Craniofacial Journal [document on the internet]; March 26, 2020 [cited 2020 Mar 26]. Available from: https://journals.sagepub.com/home/cpc.

26. These events have been postponed, cancelled or gone virtual due to coronavirus [document on the internet]; March 24, 2020 [cited 2020 Mar 26]. Available from: https://www.northstarmeetingsgroup.com/News/ Industry/coronavirus-meetings-PostponementsCancellations-COVID-19.

27. Interim Guidance for Coronavirus Disease 2019 (COVID-19) [document on the internet]; March 15, 2020 [cited 2020 Mar 26]. Available from: https://www. cdc.gov/coronavirus/2019-ncov/community/largeevents/mass-gatherings-ready-for-covid-19.html.

28. Helping businesses and schools stay connected in response to Coronavirus [document on the internet]; March 3, 2020 [cited 2020 Mar 26]. Available from: https://cloud.google.com/blog/products/g-suite/ helping-businesses-and-schools-stay-connected-inresponse-to-coronavirus.

29. Maffia F, Fontanari M, V. Vellone, Cascone P, Mercuri LG. Impact of COVID-19 on maxillofacial surgery practice: a worldwide survey. Int J Oral Maxillofac Surg 2020;49(6):827-35.

30. Tymofieiev OO, Ushko NO, Yarifa MO. Covid-2019 response: virtual educational process at the department of oral and maxillofacial surgery using Google Classroom. J Diagn Treat Oral Maxillofac Pathol 2020;4(3):51-2.

31. News and announcements. J Oral Maxillofac Pathol 2007;65(2):365-66.

32. CDE: OMFS COVID-19 Response Conference: Protecting Our Patients, Staff and Ourselves [document on the internet]; April 8, 2020 [cited 2020 Apr 8]. Available from: https://www.dental. upenn.edu/news-events/events/cde-omfs-covid-19response-conference-protecting-our-patients-staffand-ourselves/. 